\title{
English Teacher Performance in Teaching at SMAN 3 Palopo
}

\author{
Nina Utami \\ State Islamic institute of Palopo (IAIN Palopo), South Sulawesi, Indonesia \\ utaminina@iainpalopo.ac.id
}

\begin{abstract}
This thesis focused on the research questions is how the English Teacher performance in teaching, include: how the planning of the teacher before teaching, how the strategies of the teacher in teaching, and constraints that affect teacher performance in teaching at SMAN 3 Palopo. The data were collected through observation, interviews, and documents, and were analyzed using qualitative descriptive techniques. The object of the research was the teacher of SMAN 3 Palopo who has been certified. The research analyzed the data that has been found by observation and the result was explained in the discussion. The results showed that the performance of English teachers in teaching at SMAN 3 Palopo was quite good. Saw from his readiness before teaching, the selection of strategies and methods that were suitable, as well as how to deal with all the obstacles that exist.
\end{abstract}

Keywords: English Language Teaching, Teacher Performance

\section{INTRODUCTION}

Performance in the teaching of a teacher, in the education world, is important. Because teacher performance in class is a dominant factor in determining student learning motivation and quality of learning. It means if the teacher involved in learning activities has a good performance, will be able to improve the quality of learning. This can be understood because teachers who have good performance in the class will be able to explain the lesson well, be able to foster students' learning motivation well, be able to use learning media well, be able to guide and lead students in learning, so that students will have enthusiasm and motivation in learning, happy with the learning activities that are followed, and feel easy to understand the material presented by the teacher. A teacher should optimize his performance in teaching. Because of the success or failure of learning depends on the performance of the teacher (Alannasir, 2020). All aspects supporting teacher performance in learning need to be carefully considered, starting from the concept of learning, the manner of methods when teaching, material preparation, lesson plans, syllabus, learning media etc, because a wise teacher is a teacher who doesn't only think about the success of learning but he also thinks about the right way to transfer material, so that learning objectives can be achieved properly.

English language teachers must have capable skills in their fields to become professional teachers who are able to design learning as interesting as possible, to motivate students' learning spirit in learning. This is indeed not easy, especially for teachers who do not have much teaching experience. This is where the importance of the experience and insight of English teachers in teaching. Achieving a learning goal can be a benchmark for the success of a teacher's performance in teaching. Therefore, to improve 
teacher performance, teacher performance evaluations will be held annually. According to the source, the Georgia Department of Education has developed assessment instruments that will be used by educational institutions to assess teacher performance.

As times progress more rapidly, the world of education has experienced many changes, including teachers. If in the past the English teacher could only teach students in an old-fashioned way, now learning English became increasingly easy and fun. Especially with the development of increasingly creative learning media. Because English teachers also need to change their mindset about teaching English and must be able to follow the appropriate pattern of age. Teachers are not only required to be smart but also must be the best teachers. Therefore, professional teachers are indispensable in the developing world of education. the more teaching experience in teaching, the more professional the teacher will be in teaching. Professionalism is not only needed in the teaching and learning process but is also needed in the promotion process. When discussing teacher performance, the discussion we get is very broad and diverse. There has been a lot of research that discusses how teachers perform, and there have been many efforts to improve teacher performance, from the government, principals and teachers themselves. Especially the English teacher who must have the ability and excellence in the field of mastery of English in supporting the lessons that the English language teacher brings it is to realize quality education.

The English language has four sub-abilities, it is speaking, listening, reading, and writing. Each capability has its own weaknesses and strengths. It also gives some affect the way the mastery of teacher in every skill for their performance. In place of research, researchers found information about English teacher performance so inspiring that made the Senior high school number 3 in Palopo become the first favourite school in Palopo city. Based on several findings and observations from the research place, the researcher felt interested and wanted to dig deeper about "English Teachers Performance in Teaching at SMAN 3 Palopo".

\section{METHODS}

This research will apply the descriptive qualitative method. Descriptive qualitative is a method of elaboration or depiction of a situation base on what is in the place of research used by researchers. It aims to describe how English teachers' performance in teaching at SMAN 3 Palopo. This method is useful to describe of situation base on the observation place. Research is an effort to find and prove the truth scientifically. Research to be scientific if in the way it works shows certain scientific traits, namely rational, empirical and systematic.

\section{The time and the location of The Research}

- The location of the research: This research was conducted at SMAN 3 Palopo.

- The time of research: This research star from January until February 2020.

\section{Data Source}

\section{The Subject and the Object of the Research}

The subjects in this study are all four English teachers in SMAN 3 Palopo. But the researchers focused on one teacher who became a favourite teacher at the school. The object of research in this study is the performance of English teachers including teacher planning before teaching, how the teacher's strategy in implementing learning, and the obstacles

School History of SMAN 3 Palopo 
Palopo State High School 3 was established in 1975 under the name SMPP on an area of 43,288 m2 located on Jalan Jenderal Sudirman No.52 Palopo City which is now renamed Jalan Andi Djemma No. 52 Palopo City and its geographical location is very strategic because it is on a pivot road between the provinces in Palopo City. in 1985 SMPP was changed to Palopo 3 High School, 1997 became SMU and in 2004 returned to SMA and 2006/2007 school year was designated as an ICT pilot project, and 2007/2008 school year was designated as an International School Pilot Project ( RSBI) which since its establishment has experienced a change of principal including:

- Drs. H.Ibrahim Machmud, the period from 1875 to 1977

- Drs. Aminuddin R. Magi, the period from 1977 to 1982

- Zainuddin Sandra Maula, period 1982 to 1986

- Drs. H. Jamaluddin Wahid, the period from 1986 to 1999

- Drs. Abdul Rahim Kuty, period 1999 to 2003

- Drs. Muh. Zainal Abidin, the period 2003 to 2006

- Drs. Muhammad Jaya, M.Sc, period from 2006 to 2012

- Drs. Sirajuddin, the period from 2012 to 2015

- Muhammad Arsyad, S.Pd, the period of 2015 until 2017

- Hairuddin, S.Pd., M.Pd. the period of 2017 until now.

Likewise, in the teaching and learning process, several times the curriculum has changed namely:

$>1975$ curriculum

$>1984$ curriculum

$>1994$ curriculum

$>2004$ curriculum

$>2006$ SBC Curriculum

$>2013$ curriculum

$>$ Return to the 2006 SBC Curriculum 2016 National Curriculum (2013 Curriculum Improvement)

SMA Negeri 3 Palopo to date has 32 classrooms consisting of $9 \mathrm{X}$ classrooms, 11 regular classrooms for class XI (consisting of 7 science classes and 4 social science classes) and 12 classrooms for class XII (consisting of 8 science classes and 4 IPS classes). The number of class students is 32 class people.

Vision

Superior in religious quality, bringing on the national culture, environmental and international

Mission

- Growing the spirit of excellence in students intensively in accordance with the potential have encouraged and helping students to explore himself potentials that can be developed optimally and able to compete globally / international

- Growing up on the religion towards the nation culture so become a source of interest in action

- Apply participative management by involving all school citizens and school stakeholders

- Implementing optimum learning and guidance, using information and communication technology

- Developing local culture to grow nation culture 
- Encouraging and maintaining a love of a harmonic environment to all school citizens (http://www.sman3palopo.sch.id/updates)

\section{The Technique of Data Collection Observation}

The researcher will use the observation because of the researcher The technique that this research needs it to make sure immediately, how the process teacher teaching writing in SMAN 3 Palopo. In this research, the researcher applied observation to find out of the data. Techniques for collecting data through observation are:

a. The researcher wrote descriptions

- The researcher makes written descriptions of the design data that want to find out.

- Limitations include

1) The researcher might miss out on observation as they are taking notes

2) The researcher may be focussed on a particular event or situation

3) There is room for subjective interpretation of what is happening

b. Voice recording

To make clear and validity the data of the research, allows the researcher to make

a voice recording record. It makes it easy for the researcher to analyze the result of the thesis.

\section{Interview}

The interview is a technique of data collection conducted through face-to-face and direct question and answer between data collectors and researchers towards resource persons or data sources. The interview is divided into structured and unstructured interviews.

1. Structured interviews mean researchers have known exactly what information they want to extract from respondents so that the list of questions has been systematically made. Researchers can also use a tape recorder, photo camera, and other materials that can help smooth the interview.

2. Unstructured interviews are free interviews, researchers don't use interview guidelines that contain questions that will be asked specifically, and only contain important points of the problem that the respondents want to explore.

So, to find out and make clear of the data the researcher used the in-depth interview to the object of research. The researcher also used a structured interview in her research to make the interview easy and clearly.

\section{The technique of Data Analysis}

In this research, the researcher will analyze the data that has been obtained from the research site using analytical methods to study the results of the research. Includes strategies used by the teaching teacher, teacher planning before teaching, and the obstacles that teachers commonly encounter when teaching. After that, researchers will summarize the results of research into a conclusion. From that conclusion, the researcher will find out how the results of his research.

\section{RESULTS}

Based on the results of observations, interviews, and documentation that has been done, as described in the previous chapter that the purpose of this study is to describe how the performance of English teachers in teaching at SMAN 3 Palopo. Includes what 
the English teacher prepares before teaching, what strategies are used in teaching as well as what are the obstacles experienced by the teacher while teaching at school. So there are a number of points discovered by researchers while in the study area, including;

1. Teacher Planning Before Teaching

Making preparation before teaching is very important. Preparing everything before teaching will facilitate the teacher in the process of transferring knowledge to students, making it easier in the process of providing grades (evaluation), and making it easier for teachers to achieve learning goals. The things that the teacher prepares before teaching are important aspects that must be prioritized. Designing learning preparation must be as detailed and as good as possible. The better the preparation is designed, the easier it is for the teacher to manage the class.

Every year before starting a new school year, teachers at SMAN 3 Palopo will be asked to make various learning tools. Learning tools are a very important supporting component in learning. Various types of learning tools include syllabi, lesson plans, annual programs, semester programs, assessment sheets, and most importantly appropriate teaching materials for students. Teachers at SMAN 3 Palopo must also prepare learning media in the form of teaching aids and textbooks in accordance with teaching materials and relevant to students' needs.

2. Teacher English Strategy

All educators who are professional and obey the rules must prepare everything before they teach, like also the teacher at SMAN 3 Palopo. In preparation for the delivery of learning material, the teacher at SMAN 3 Palopo reviews or observes the class needs that must be known by the teacher. Observing class needs is done at the beginning of the meeting. So at the next meeting, the teacher will determine a strategy or method that is suitable for students in the class to be taught. Based on the statements given by the teacher in the interview process, the teacher said that in determining the appropriate strategy for the learning process is optional. This is based on class needs. However, from the teacher's statement, he said that he often uses expository strategies. According to the teacher, this strategy is suitable for the majority of the classes he teaches. In addition to the expository strategy, he also uses strategies to improve thinking skills and demonstrations. Because this strategy is considered suitable with the cognitive abilities of students.

3. The obstacles that affect the performance of teachers

In carrying out their duties, there are no teachers who do not encounter obstacles and problems. So did the teacher at SMAN 3 Palopo. Some of the obstacles experienced by teachers at SMAN 3 Palopo when teaching.

- Basic Skills of Students

The basic abilities of students in speaking English at SMAN 3 Palopo began to decline dramatically in recent years. Because of the basic English skills that students should master when in middle school, in high school students just start studying. This makes it difficult for English teachers to deliver lessons. The teacher must be patient and diligent in teaching because the ability of students in English is very limited. At the high school level, students should have mastered many abilities in English.

- Zonation System

A zoning system is a process of separating zones or areas which are divided into sections according to the function and purpose of the division. Like other schools that 
feel the zoning system, SMAN 3 Palopo is also one of the schools that feel the zoning system. This has a big influence on schools, especially teachers. With the zoning system, teachers must work harder in educating students. That is because the cognitive abilities of students are far below, compared to before when the school had not experienced the zoning system. Formerly, SMAN 3 Palopo used to select highachieving students from superior junior high schools to attend SMAN 3 Palopo. Automatically the teacher's performance is made easier and lighter because the students of SMAN 3 Palopo used to have high cognitive abilities. In contrast to now, because the school does not have a selection system, finally students who do not have good cognitive abilities can go to school at SMAN 3 Palopo.

- Facilities and infrastructure

It's a public secret that every school has its own problems and obstacles. As well as facilities and infrastructure issues, each school will experience something that will affect the learning process. Even favourite schools like SMAN 3 Palopo are not free from problems. At SMAN 3 Palopo, there are still difficulties with the procurement of textbooks to support the teaching and learning process. This makes the situation of the teaching and learning process isn't conducive as a whole, even though the teaching and learning process has lasted two months. However, for two months students learn to use makeshift books. the teacher is forced to look for books that can support student learning. and each student has to pay quite expensive. In addition, worship infrastructure is also inadequate. Small school prayer rooms make students have to queue to perform worship. The queuing event sometimes makes learning hours begin to be delayed.

\section{DISCUSSION}

1. Teacher Planning Before Teaching

According to the researcher, the teacher's preparation before teaching was good and organized. This can be seen from the completeness of the teacher administration files shown by the teacher to the researcher during the observation process. However, teachers in this decade have been very busy with the activities of preparing learning tools. Such as annual programs, semester programs, syllabi, learning plans and assessment sheets.

2. Teacher English Strategy

Talking about strategies and methods, the teacher at SMAN 3 Palopo said that they were conditional. That is because the ability in terms of mastery of basic material from each class is varied, different. Then the learning motivation of students from each class also tends to be different. What is clear from the many strategies that are often used in teaching students at SMAN 3 Palopo is expository strategy. Where expository is a communicative learning strategy in the process of delivering material verbally. Why do the teachers at SMAN 3 Palopo prefer this strategy, because students are more likely to pay attention to the teacher when explaining the material in a thick manner. Moreover, the ability of students with respect to the material tends to be lacking too, and when observed students pay more attention to the teacher when the teacher uses an expository strategy.

Because expository strategy means the method that is relevant to the strategy is the lecture method and sometimes the demonstration method. Although sometimes also using other strategies as stated earlier that it is conditional, depending on student 
motivation, the basic abilities of students and the material to be taught, the level of difficulty and other causes. Sometimes teachers in these schools use learning strategies to improve thinking skills. So the method used in this strategy is the method of discussion and question and answer. Sometimes also using other strategies, namely cooperative / group learning strategies, of course, it is more prioritizing or more often used the discussion method when the strategy is used.

3. The obstacles that affect the performance of teachers

It's not that the teacher doesn't want to be bothered or picky about students, but based on the facts at the research location, the teacher has complained about this. Indeed, it has become the responsibility and risk of being a teacher to face all obstacles that arise. But this problem needs serious handling from the government. This is also for the good name of SMAN 3 Palopo.

\section{CONCLUSION}

Based on the results of an analysis of the activities carried out by researchers at SMAN 3 Palopo about English Teacher performance in teaching, then it can be concluded as follows:

1) The performance of English teachers in teaching at SMAN 3 Palopo is good. This is seen based on direct observations and research that has been done, which shows that in educating and teaching at SMAN 3 Palopo, teachers are in accordance with professional criteria and are highly dedicated to their profession.

2) The use of strategies and methods in learning is good. Because the teacher can manage the class and identify the needs of students in each class being taught.

\section{BIBLIOGRAPHY}

Alannasir, W. (2020). Characteristic-Based Development Students Aspect. International Journal of Asian Education, 1(1), 29-36. https://doi.org/10.46966/ijae.v1i1.18

Daphne D. Minner, Abigail Jurist Levy, Jeanne Century. 2009. Inquiry-Based Science Instruction-What Is It and Does It Matter?. The University of Chicago.

David F. Lohman. 1997. Issues in The Definition and Measurement of Abilities, (The University of Iowa, USA)

EP Ques Appendixes.1988. Model of Arbitrator Competence.

Gandara.P, Maxwell-Jolly.J, Driscoll.A .2005. Listening to Teachers of English Language Learners. (The Regents of the University of California)

Goldenberg, C. 2008. Teaching English Language Learners: What the Research Does - And Does Not - Say; Georgia Southern University.

Goldhaber, DD. and Dominic J. Brewer. 1996. Evaluating the Effect of Teacher Degree Level on Educational Performance; Santa Monica.

Madjid, Abd. 2016. Pengembangan Kinerja Guru Melalui: Kompetensi, Komitmen dan Motivasi Kerja, Yogyakarta: Samudra Biru.

Ning Zahroh, Mas. Evaluasi Kinerja dalam Peningkatan Mutu Pendidikan di Yayasan Al Kenaniyah Jakarta Timur; Jakarta Timur. 
Philippe Dessus, Sonia Mandin, and Virginie Zampa.2008. What is Teaching? CognitiveBased Tutoring Principles for the Design of a Learning Environment. (Common innovation in e-learning, machine learning and humanoid.

Rain S. Bongolan. 2005. Six Key Strategies for Teachers of English-Language Learners; University of California at Santa Cruz.

Spronken-Smith, R. 2006. Experiencing the Process of Knowledge Creation: The Nature and Use of Inquiry-Based Learning in Higher Education. University of Otago, New Zealand.

Villegas- Reimers, E.2003. Teacher Professional Development: An International Review of the Literature. International Institute for Educational Planning.

Villegas-Reimers, Eleonora. 1994. Teacher professional development: an international review of the literature.

Yusrus Sana, Mohammad. 2006. Penilaian Kinerja Guru Mengenai Profesionalisme Guru di SMP NU Putri Kartika Kab.Kudus. Semarang.

Zamel, V. 1982. Writing: The Process of Discovering Meaning. (TESOL Quarterly is currently published by Teachers of English to Speakers of Other Languages, Inc.) 